\title{
The effects of grouping types on promoting critical thinking in EFL collaborative writing
}

\author{
Nguyen Thi Minh Tram ${ }^{1 *}$, Bui Thi Thuc Quyen ${ }^{2}$ \\ ${ }^{1}$ University of Social Sciences and Humanities - Vietnam National University Ho Chi Minh \\ City, Vietnam \\ ${ }^{2}$ Ho Chi Minh City Open University, Vietnam \\ *Corresponding author: tramnguyenqnu@gmail.com
}

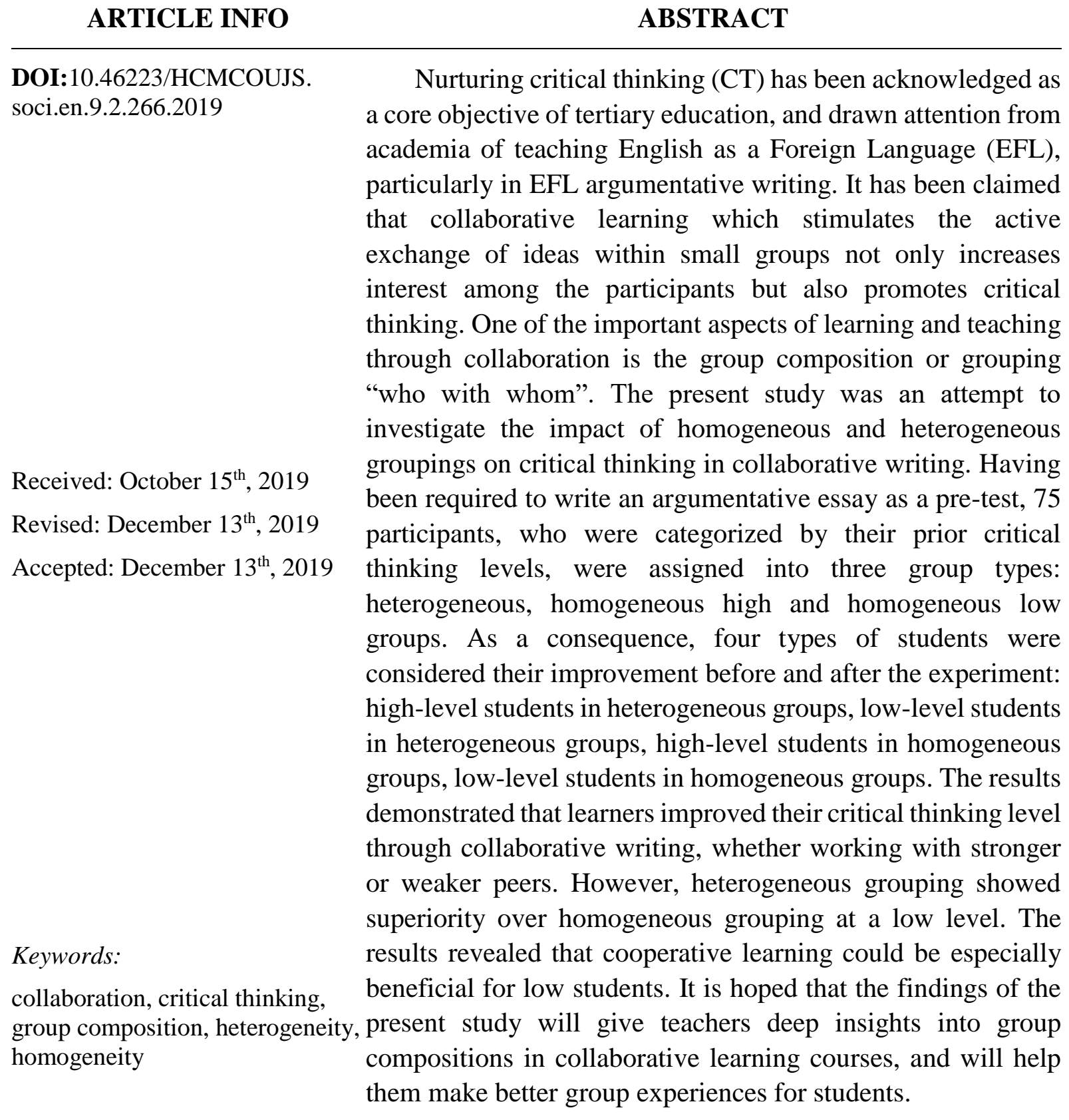




\section{Introduction}

Today's modern methods of learning have gradually shifted from passive learning to active learning in order to encourage teachers and students to enhance their intellectual efforts through interaction, with the aim of exploring, understanding, generating ideas and finally creating a product. Collaborative learning has been employed to improve many different aspects of learning English as a foreign language, particularly critical thinking in writing argumentative essays. It is proposed that active learning is of utmost importance in stimulating language learners to think critically (Burbach, Matkin, \& Fritz, 2004; Tedesco-Schneck, 2013; Walker, 2003). In parallel with the emphasis on the importance of collaborative learning in the class, a question of equal or greater significance centers around the effect of the composition of the group, that is, grouping "who with whom". There are two major grouping methods, including heterogeneous (i.e., of the mixed types) and homogeneous (i.e., of the same type) grouping. Previous researchers have expressed different views about the effects of heterogeneous and homogeneous ability-grouping on student learning. Some researchers believe heterogeneous grouping benefits student learning more than homogeneous grouping. Whereas, other researchers have supported homogeneous grouping. This study aims to have a more in-depth view of the effects of group composition on promoting the critical thinking level of ELF students in collaborative writing.

\section{Literature review}

\subsection{Critical thinking and its relationship with argumentative writing}

As a term with multiple definitions, critical thinking (CT) broadly comprises skills and disposition. Critical thinking skills are concerned with cognitive skills such as interpretation, analysis, evaluation, explanation, inference, and self-regulation, while critical thinking disposition relates to the affective domain, including inquisitiveness, systematicity, analyticity, truth-seeking, open-mindedness, self-confidence, and maturity (Facione, Facione, \& Sánchez, 1994).

The primary foundation of the theoretical framework related to argumentative essays is the Toulmin model of argumentation. In 1958, Toulmin presented a model of the six elements in producing a good argument (Toulmin, 2003). The first three elements consisting of a claim, data, and warrants, which are essential to any argument. First, a person makes a claim (i.e., an assertion, standard, or thesis). Next, the data (i.e., facts or evidence) are provided to support the claim. Finally, the warrants link the data to the claim and give the data general support. Besides, three additional elements are also involved in the Toulmin model, including qualifiers (i.e., the degree of force which the data confer on the claim in virtue of the warrants), rebuttals (i.e., conditions of exception indicating circumstances in which the general authority of the warrant would have to be set aside) and backing (i.e., providing reinforcement for the warrants).

However, due to its complexity, Toulmin's model has been applied in a more simplified way and its elements have been given different names bearing the original meaning. For instance, the claim has been termed 'proposition', 'opinion', or 'conclusion'; data has been named 'reasons', 'evidence', or 'arguments'. The terms qualifier and backing have been used 
less often in empirical studies. The term rebuttal, together with a qualifier, has been elaborated into counterarguments and rebuttals (e.g., Knudson, 1992), to refer to the whole process of counter-argumentation by acknowledging alternative or opposite views and refuting them. The significance of CT including counterarguments and rebuttals for making written argumentation persuasive has been underpinned by much research. In the L1 context, counter-argumentation, an arguer's recognition of opposing views and refuting them, has been deemed central to one's CT abilities and dispositions (Palmer, 2012; Perkins \& Tishman, 2001; Walton, 1989). Meanwhile, in the L2 context, studies on L2 students' argumentative writing and critical thinking are fewer in number. A study conducted by Qin and Karabacak (2010) found that when counterarguments and rebuttals were included, they enhanced the overall quality of argumentative writing. In short, elements of critical thinking (i.e., argumentation and counterargumentation) play an integral part of assessing an argumentative essay; in contrast, argumentative writing including the practice of making arguments, giving opposite views and refuting them helps students promote their critical thinking level.

\subsection{Collaborative learning in improving critical thinking}

Proponents of collaborative learning claim that the active exchange of ideas within small groups not only increases interest among the participants but also promotes critical thinking. According to Johnson and Johnson (1986), there is persuasive evidence that cooperative teams achieve at higher levels of thought and retain information longer than students who work quietly as individuals. The shared learning gives students an opportunity to engage in discussion, take responsibility for their own learning, and thus become critical thinkers (Totten, Sills, Digby, \& Russ, 1991).

When carrying out a collaborative learning activity, one of the concerns is finding the most appropriate grouping of students that is able to maximize learning. In the literature, discussion on the grouping of students revolves around the size of the group, the selection of group members and the duration of group work. A review of related research indicates that most empirical studies have examined the effects of heterogeneous and homogeneous abilitygrouping on students' learning. Studies on comparing the effect of heterogeneous and homogeneous grouping have been conducted (Baer, 2003; Camara, Carr, \& Grota, 2007; Faris, 2009; Larson, Clayson, \& Clawson, 1984; Watson \& Marshall, 1995), but the issue is still controversial among researchers of all disciplines.

With regard to examining the impact of grouping on fostering students' critical thinking, there are few studies in which students are divided into groups based on their reasoning level. A study conducted by Jensen and Lawson (2011) revealed that group composition (homogeneous vs. heterogeneous) appears to have a variety of effects on achievement on highlevel items (items requiring more high-level skills). Low-level students of critical thinking tend to perform better when placed in homogeneous groups, whereas medium and high-level ones performed equally in both group compositions. However, Jenson and Lawson's study considered reasoning as a separate skill; that is, it is not used in combination with other skills (e.g., reading or writing). 
Although there has been a growing body of literature and empirical studies in the field of collaborative learning in EFL teaching and learning, most of them conducted aim to investigate the impacts of collaborative learning on improving students' achievement as well as their critical thinking in various areas of language. In addition, research pertaining to the influence of grouping factors has been conducted in Western countries whose collaborative learning principles may not suit Asian culture in general and Vietnamese culture in particular. Therefore, there is a need to carry out an empirical study that investigate the effect of grouping types on fostering Vietnamese students' critical thinking in collaborative writing.

\subsection{Research questions}

The present paper seeks to justify how much homogeneous and heterogeneous grouping of EFL learners working collaboratively affects their critical thinking level in writing argumentative essays. Furthermore, it also attempts to determine the effects of these two group types on improving the critical thinking level of high-level and low-level students. It is noted that the level of students in this study is categorized based on their initial CT level on the pretest.

The study aims to answer three research questions as follows:

1/ Are there any statistically significant changes in the CT level of homogeneous and heterogeneous groups of the participants through collaborative writing?

2/ Are there any statistically significant changes in the CT level of homogeneous and heterogeneous groups among low-level students?

3/ Are there any statistically significant changes in the CT level of homogeneous and heterogeneous groups among high-level students?

\section{Method}

\subsection{Research setting}

The present study was carried out at the Foreign Language Department - Quy Nhon University (FLD - QNU), which is located in Quy Nhon city.

\subsection{Design}

This study is quantitative research in which a quasi-experimental design was used in order to investigate and make a comparison of the effects of homogeneous and heterogeneous grouping on students' CT in collaborative writing. In this experiment, three experiment groups were employed so as to compare their effects on improving students' CT: (1) heterogeneous groups including both high and low-level students, (2) high-level homogeneous groups consisting of high-level students, and (3) low-level homogeneous groups where low-level students work collaboratively. The process of grouping was implemented randomly by assigning the participants who had taken the pre-test into one of three experimental groups based on their initial scoring of CT level. It is noted that no control group was presented in this study. 


\subsection{Instruments}

Two major instruments were used in the present study: writing prompts and the scoring rubric for assessing critical thinking in essays. The participants were given a topic of argumentative writing to write as a pre-test. The purpose of the administration of the pre-test was to identify low-level and high-level students with respect to their ability to think critically so that they could be divided into three different group types. The topic used at the beginning of the experiment was also given to the participants to write and to be scored as the post-test in the end. Besides, there are eight other topics employed during the experiment. Four topics were also used to have the groups work together and make a joint composition at the end of the week during the four-week experiment. The others were given to all of the participants to write individually every week.

The present study employed the 4-point rubrics following Stapleton (2001) to evaluate elements of CT in argumentative writing.

This model was chosen because its elements are in accordance with the Toulmin model of argumentation which emphasizes the importance of identifying and refuting the opposite views.

\section{Findings and discussion}

Question 1: Are there any statistically significant changes in the CT level of homogeneous and heterogeneous groups of the participants through collaborative writing?

To figure out the answer to question 1, the first hypothesis was proposed that there is not any statistically significant difference in the critical thinking level of homogeneous and heterogeneous groups of EFL learners through collaborative writing. A tabulation of descriptive statistics is shown in Table 1 below.

\section{Table 1}

Descriptive statistics of grouping strategy and ability level

\begin{tabular}{|l|c|c|c|}
\hline \multicolumn{1}{|c|}{ Group } & N & Mean - Pre test & Mean - Post test \\
\hline $\begin{array}{l}\text { Heterogeneous high } \\
\text { (hete-high) }\end{array}$ & 12 & 3.42 & 3.83 \\
\hline $\begin{array}{l}\text { Homogeneous high } \\
\text { (homo-high) }\end{array}$ & 15 & 1.47 & 2.87 \\
\hline $\begin{array}{l}\text { Heterogeneous low } \\
\text { (hete-low) }\end{array}$ & 20 & 3.40 & 3.95 \\
\hline $\begin{array}{l}\text { Homogeneous low } \\
\text { (homo-low) }\end{array}$ & 26 & 1.58 & 1.92 \\
\hline
\end{tabular}

Source: The researcher's data analysis

Table 1 summarizes the mean of pre-test and post-test of four types of students: highlevel students in heterogeneous groups, low-level students in heterogeneous groups, high-level students in homogeneous groups, low-level students in homogeneous groups. It can be seen that 
there was an increase in the mean of the pre-test and the post-test of both low-level and highlevel students was shown in both types of grouping. Nevertheless, the difference between the means of students at the pre-test and post-test is significant or not is of greater importance. Paired sample t-tests were run to have an in-depth understanding of the question (see Tables 2 , 3, 4 and 5).

\section{Table 2}

Paired sample t-test for heterogeneous high students

\begin{tabular}{|c|c|c|c|c|c|c|c|c|c|}
\hline & \multicolumn{5}{|c|}{ Paired Differences } & \multirow[b]{3}{*}{$\mathrm{t}$} & \multirow[b]{3}{*}{ df } & \multirow{3}{*}{$\begin{array}{l}\text { Sig. } \\
\text { (2-taile } \\
\text { d) }\end{array}$} \\
\hline & & \multirow[b]{2}{*}{ Mean } & \multirow{2}{*}{$\begin{array}{c}\text { Std. } \\
\text { Deviation }\end{array}$} & \multirow{2}{*}{$\begin{array}{l}\text { Std. } \\
\text { Error } \\
\text { Mean }\end{array}$} & \multicolumn{2}{|c|}{$\begin{array}{l}95 \% \text { Confidence } \\
\text { Interval of the } \\
\text { Difference }\end{array}$} & & & \\
\hline & & & & & Lower & Upper & & & \\
\hline Hete-high & $\begin{array}{l}\text { Post - } \\
\text { Pre }\end{array}$ & .41667 & .51493 & .14865 & .08950 & .74384 & 2.803 & 11 & .017 \\
\hline
\end{tabular}

Source: The researcher's data analysis

It can be seen from Table 1 that the mean scores of heterogeneous high students on preand post-test were 3.42 and 3.83 respectively; whereas, the mean scores of heterogeneous low students on pre- and post-test were 1.47 and 2.87 respectively. The result of the paired sample t-test showed that there was a significant difference between the mean scores of the heterogeneous high students on the pre- and post-test through collaborative writing, $t=2.803$, $\mathrm{p}<0.05$ (see Table 2).

\section{Table 3}

Paired sample t-test for heterogeneous low students

\begin{tabular}{|c|c|c|c|c|c|c|c|c|c|}
\hline & & & Paire & Differe1 & & & & & \\
\hline & & & Std. & $\begin{array}{l}\text { Std. } \\
\text { Error }\end{array}$ & $\begin{array}{r}95 \% \text { Co } \\
\text { Interva } \\
\text { Diffe }\end{array}$ & $\begin{array}{l}\text { fidence } \\
\text { of the } \\
\text { ence }\end{array}$ & & & $\begin{array}{c}\text { Sig. } \\
\text { (2-taile }\end{array}$ \\
\hline & & Mean & Deviation & Mean & Lower & Upper & $\mathrm{t}$ & df & d) \\
\hline $\begin{array}{l}\text { Hete } \\
\text {-low }\end{array}$ & $\begin{array}{l}\text { Post - } \\
\text { Pre }\end{array}$ & 1.40000 & .50709 & .13093 & 1.11918 & 1.68082 & 10.693 & 14 & .000 \\
\hline
\end{tabular}

Source: The researcher's data analysis

Table 3 shows that heterogeneous low students also improved on the post-test (their mean scores on the pre-test were 1.47 , which increased to 2.87 on the post-test) and their mean difference was significant, $\mathrm{t}=10.693, \mathrm{p}<0.05$. 


\section{Table 4}

Paired sample t-test for homogeneous high students

\begin{tabular}{|c|c|c|c|c|c|c|c|c|c|}
\hline & \multicolumn{5}{|c|}{ Paired Differences } & \multirow[b]{3}{*}{$t$} & \multirow[b]{3}{*}{ df } & \multirow{3}{*}{$\begin{array}{l}\text { Sig. } \\
\text { (2-taile } \\
\text { d) }\end{array}$} \\
\hline & & \multirow[b]{2}{*}{ Mean } & \multirow{2}{*}{$\begin{array}{c}\text { Std. } \\
\text { Deviation }\end{array}$} & \multirow{2}{*}{$\begin{array}{l}\text { Std. } \\
\text { Error } \\
\text { Mean }\end{array}$} & \multicolumn{2}{|c|}{$\begin{array}{l}95 \% \text { Confidence } \\
\text { Interval of the } \\
\text { Difference }\end{array}$} & & & \\
\hline & & & & & Lower & Upper & & & \\
\hline $\begin{array}{l}\text { Homo } \\
\text {-high }\end{array}$ & $\begin{array}{l}\text { Post - } \\
\text { Pre }\end{array}$ & .55000 & .51042 & .11413 & .31112 & .78888 & 4.819 & 19 & .000 \\
\hline
\end{tabular}

Source: The researcher's data analysis

The same results were obtained for both homogeneous high and low students. The homogeneous high students' mean scores on the pre-test and post-test were 3.40 and 3.95 respectively and the difference was significant, $\mathrm{t}=4.819, \mathrm{p}<0.05$ (see Table 4 ).

\section{Table 5}

Paired sample t-test for homogeneous low students

\begin{tabular}{|c|c|c|c|c|c|c|c|c|c|}
\hline & \multicolumn{5}{|c|}{ Paired Differences } & \multirow[b]{3}{*}{$\mathrm{t}$} & \multirow[b]{3}{*}{ df } & \multirow{3}{*}{$\begin{array}{l}\text { Sig. } \\
\text { (2-taile } \\
\text { d) }\end{array}$} \\
\hline & & \multirow[b]{2}{*}{ Mean } & \multirow{2}{*}{$\begin{array}{c}\text { Std. } \\
\text { Deviation }\end{array}$} & \multirow{2}{*}{$\begin{array}{l}\text { Std. } \\
\text { Error } \\
\text { Mean }\end{array}$} & \multicolumn{2}{|c|}{$\begin{array}{l}95 \% \text { Confidence } \\
\text { Interval of the } \\
\text { Difference }\end{array}$} & & & \\
\hline & & & & & Lower & Upper & & & \\
\hline $\begin{array}{l}\text { Homo } \\
\text {-low }\end{array}$ & $\begin{array}{l}\text { Post - } \\
\text { Pre }\end{array}$ & .34615 & .48516 & .09515 & .15019 & .54212 & 3.638 & 25 & .001 \\
\hline
\end{tabular}

Source: The researcher's data analysis

Homogeneous low students' mean scores were 1.58 and 1.92 on the pre- and post-test respectively, and the difference was the statistical difference as suggested by a paired sample $\mathrm{t}$ test and the results, $\mathrm{t}=3.638, \mathrm{p}<0.05$ (see Table 5).

Therefore, it could be concluded that the first hypothesis which said that there is not any statistically significant difference in the critical thinking level of students in both heterogeneous and homogeneous groups through cooperative writing was rejected. In a word, the students have the same chances to gain some improvements in their critical thinking level through writing collaboratively.

Question 2: Are there any statistically significant changes in the CT level of homogeneous and heterogeneous groups among high-level students categorized by their initial CT level?

The second hypothesis states that there is not any statistically significant difference in the critical thinking level of homogeneous groups and heterogeneous groups among low-level 
EFL learners through cooperative writing. As can be seen from table 1, heterogeneous low students obtained a higher mean gain, i.e., 1.40 than the homogeneous ones $(0.35)$.

This reveals that the heterogeneous grouping has been more effective in improving the critical thinking level for low-level students. In other words, low students have gained more improvement as a result of working with higher peers than working with students of the same level. In order to examine whether the difference between the mean scores of heterogeneous low and homogeneous low students was significant or not, an independent t-test was run and it is shown that the Levene's test is statistically significant with $\mathrm{p}<.05$ as shown in Table 6 below.

\section{Table 6}

Independent t-test for low homogeneous and heterogeneous students

\begin{tabular}{|c|c|c|c|c|c|c|c|c|c|c|}
\hline & \multicolumn{2}{|c|}{$\begin{array}{l}\text { Levene's } \\
\text { Test for } \\
\text { Equality of } \\
\text { Variances }\end{array}$} & \multicolumn{7}{|c|}{ t-test for Equality of Means } \\
\hline & & \multirow[b]{2}{*}{$\mathrm{F}$} & \multirow[b]{2}{*}{ Sig. } & \multirow[b]{2}{*}{$t$} & \multirow[b]{2}{*}{ df } & \multirow{2}{*}{$\begin{array}{l}\text { Sig. } \\
\text { (2-tail } \\
\text { ed) }\end{array}$} & \multirow{2}{*}{$\begin{array}{c}\text { Mean } \\
\text { Difference }\end{array}$} & \multirow{2}{*}{$\begin{array}{l}\text { Std. Error } \\
\text { Difference }\end{array}$} & \multicolumn{2}{|c|}{$\begin{array}{l}95 \% \text { Confidence } \\
\text { Interval of the } \\
\text { Difference }\end{array}$} \\
\hline & & & & & & & & & Lower & Upper \\
\hline \multirow[t]{2}{*}{ Gain } & $\begin{array}{l}\text { Equal } \\
\text { variances } \\
\text { assumed }\end{array}$ & .395 & .039 & 6.591 & 39 & .000 & 1.05385 & .15990 & .73043 & 1.37727 \\
\hline & $\begin{array}{l}\text { Equal } \\
\text { variances } \\
\text { not } \\
\text { assumed }\end{array}$ & & & 6.511 & 28.275 & .000 & 1.05385 & .16185 & .72245 & 1.38524 \\
\hline
\end{tabular}

Source: The researcher's data analysis

Therefore, the second hypothesis states that there is not any statistically significant difference in the critical thinking level of homogeneous groups and heterogeneous groups among low-level EFL learners through cooperative writing was rejected.

Question 3: Are there any statistically significant changes in the CT level of homogeneous and heterogeneous groups among high-level students categorized by their initial CT level?

The third hypothesis states that there is not any statistically significant difference in the critical thinking level of homogeneous groups and heterogeneous groups among high-level EFL learners through cooperative writing. Although both homogeneous and heterogeneous students achieved higher mean scores at the post-test in comparison with the pre-test, homogeneous high students proved to outperform heterogeneous high students. As can be seen from table 1, homogeneous high students obtained a higher mean gain than the heterogeneous ones $(0.55$ and 
0.41 respectively). This discloses that the homogeneous grouping has been more effective for the improvement of the critical thinking level of high-level students.

An independent t-test was also run to compare the mean scores of high students in heterogeneous and homogeneous groups.

\section{Table 7}

Independent t-test for high homogeneous and heterogeneous students

\begin{tabular}{|c|c|c|c|c|c|c|c|c|c|c|}
\hline & \multicolumn{2}{|c|}{$\begin{array}{l}\text { Levene's } \\
\text { Test for } \\
\text { Equality of } \\
\text { Variances }\end{array}$} & \multicolumn{7}{|c|}{ t-test for Equality of Means } \\
\hline & & \multirow[b]{2}{*}{ F } & \multirow[b]{2}{*}{ Sig. } & \multirow[b]{2}{*}{$\mathrm{t}$} & \multirow[b]{2}{*}{ df } & \multirow{2}{*}{$\begin{array}{l}\text { Sig. } \\
\text { (2-tail } \\
\text { ed) }\end{array}$} & \multirow{2}{*}{$\begin{array}{c}\text { Mean } \\
\text { Difference }\end{array}$} & \multirow{2}{*}{$\begin{array}{l}\text { Std. Error } \\
\text { Difference }\end{array}$} & \multicolumn{2}{|c|}{$\begin{array}{l}95 \% \text { Confidence } \\
\text { Interval of the } \\
\text { Difference }\end{array}$} \\
\hline & & & & & & & & & Lower & Upper \\
\hline \multirow[t]{2}{*}{ Gain } & $\begin{array}{l}\text { Equal } \\
\text { variances } \\
\text { assumed }\end{array}$ & 4.639 & .533 & -1.619 & 30 & .116 & -.38333 & .23680 & -.86694 & .10028 \\
\hline & $\begin{array}{l}\text { Equal } \\
\text { variances } \\
\text { not } \\
\text { assumed }\end{array}$ & & & -1.438 & 16.021 & .170 & -.38333 & .26666 & -.94857 & .18190 \\
\hline
\end{tabular}

Source: The researcher's data analysis

The result is shown in Table 7, indicating that the Levene's test is statistically significant with $\mathrm{p}>.05$. In other words, the third hypothesis could not be rejected.

In general, the results obtained in the study show that both low-level and high-level students boosted their critical thinking levels through writing in groups of the same or different levels. However, heterogeneous grouping seems to be preferable to homogeneous one, particularly among low-level students. This can be explained by the collaboration in which lower level students "are more likely to receive the support they need from more capable peers, low-ability students learn more by being in groups with higher-ability students" (Saleh, Lazonder, \& De Jong, 2005, p. 107). This conclusion is consistent with the notion of the zone of proximal development (ZPD) developed by Vygotsky, who believed that a student's development was not able to be separated from their social settings; specifically, students could learn more than they could on their own by working with more capable peers or adults social settings. This has been referred to as "Scaffolding". The important point about the metaphor of scaffolding is that after completing the task jointly, the learner will likely be able to perform the task independently next time. Ellis (2013) also reiterated that to benefit from interactions and exchanges, the L2 learners need to communicate with someone who has sufficient proficiency in the target language to ensure that the input is not just at the learner's level, but at 
times, slightly beyond it. In addition, it was also found that verbal scaffolding and conversation with lecturers and peers allowed students to extend their ZPD for critical thinking. Therefore, the researcher reached the conclusion that students with a lower level of critical thinking get more help and feedback from their more advanced partners in heterogeneous groups than from the peers of the same level in homogeneous groups; as a result, they can improve their own CT level and perform the task better by themselves.

In contrast, the result of the study shows that homogeneous groupings proved to be a preference for high-level students. This lends support to previous findings in the literature. For example, Knufer (1993), Baron (1994), and Fuchs, Fuchs, Hamlett, and Karns (1998) suggested that high achievers performed better in homogeneous groups than in heterogeneous groups. This can be explained by the fact that high achievers in homogeneous groups were supported by the peers who were of the same or higher level than them, which caused them to achieve more advanced gains. In addition, to support from their peers, they also had support from the teacher who engaged them in advanced activities that were suitable for their level (Ediger, 2001). Nevertheless, the study also indicates that the difference between the mean scores of heterogeneous high students and those of homogeneous high students is not statistically significant, which means that the high-level students in the heterogeneous group achieved as much as high-level students in the homogeneous group despite the fact that they spent considerable time working with less capable peers in the same group (Johnson, Skon, \& Johnson, 1980; Nattiv, 1994; Webb, Troper, \& Fall, 1995). It was also demonstrated that high achievers got more benefits from working with lower level peers as a consequence of constructing more explanations than being grouped with their peers of the same level.

\section{Conclusion and implication}

The result of this study has shed light on how much high-level and low-level students promote their critical thinking level through collaborative writing when grouped homogeneously and heterogeneously, which has still been a rather "strange" topic in Vietnamese context. The findings reveal that collaborative writing can boost critical thinking levels among both high and low-level students regardless of whom they are grouped with. However, low-level students were found to maximize their level if grouped with their higher peers who can assist them in explaining and developing ideas in a critical way. Whereas, highlevel students were seen to increase their level in both group types despite the fact that they had to support their lower peers in the heterogeneous group.

As to the effect of collaborative learning, novice teachers are recommended to make the students cooperate with their classmates. However, Vietnamese students usually do not tend to work or learn cooperatively, and they do not feel comfortable with this kind of learning. It does not imply that teachers have to give up using this approach in their classes. It means that teachers need to aware their students of the benefits and advantages of cooperative learning, and put emphasis on the importance of their participation in the classroom work, and let them get habituated to it through practice. In the present study, the researcher observed that the discomfort which the students felt at the beginning of the semester changed dramatically. They became involved with each other very well. 


\section{Recommendation}

Because of the fact that there have been a variety of facets of collaborative learning and group composition, the researcher tried to limit the scope of the current study. Therefore, future research is needed to deal with the following issues:

First, since this is a case study which is aimed to undertake an in-depth view of the effects of group composition on promoting critical thinking in writing at a specific research site, the researcher only involved a small-size population that might limit the generalization of the result of this study.

Second, there can be other researches that investigate the effect of group types on using critical thinking in the other skills of the language like reading and speaking.

Third, in the present study, the researcher randomly assigned participants to either group. Future research can be conducted to find out whether students' preference to choose their favorable partners has any positive effect on their critical thinking ability in writing or other language skills.

Fourth, future research can take a mixed-method approach which incorporates qualitative and quantitative methods in different phases to obtain a broader perspective on how students of both high and low level interact with each other when grouped heterogeneously and homogeneously.

\section{References}

Baer, J. (2003). Grouping and achievement in cooperative learning. College Teaching, 51(4), 169-174.

Baron, J. B. (1994). Using multi-dimensionality to capture verisimilitude: Criterion-references performance-based assessments and the ooze factor. Paper presented at the Annual Meeting of the American Educational Research Association, New Orleans, LA.

Burbach, M. E., Matkin, G. S., \& Fritz, S. M. (2004). Teaching critical thinking in an introductory leadership course utilizing active-learning strategies: A confirmatory study. College Student Journal, 38(3), 482-493.

Camara, J. E., Carr, B. N., \& Grota, B. L. (2007). One approach to formulating and evaluating student work groups in legal environment of business courses. Journal of Legal Studies Education, 24, 1-18. doi:10.1111/J.1744-1722.2007.00032.X

Ediger, M. (2001). Homogeneous grouping and heterogeneous grouping. Retrieved September 20, 2016, from https://files.eric.ed.gov/fulltext/ED455536.pdf

Ellis, N. C. (2013). Second language acquisition. In The Routledge handbook of second language acquisition (p. 193).

Facione, N. C., Facione, P. A., \& Sánchez, C. A. (1994). Critical thinking disposition as a measure of competent clinical judgment: The development of the California critical thinking disposition inventory. Journal of Nursing Education, 33(8), 345-350. 
Faris, O. (2009). The impact of homogeneous vs. heterogeneous collaborative learning groups in multicultural classes on the achievement and attitudes of nine graders towards learning Science. Retrieved September 28, 2016, from http://files.eric.ed.gov/fulltext/ED504109.pdf

Fuchs, L., Fuchs, D., Hamlett, C., \& Karans, K. (1998). High-achieving students' interactions and performance on complex mathematical tasks as a function of homogeneous and heterogeneous pairings. American Educational Research Journal, 35, 227-267.

Jensen, J. L., \& Lawson, A. (2011). Effects of collaborative group composition and inquiry instruction on reasoning gains and achievement in undergraduate Biology. CBE-Life Sciences Education, 10(1), 64-73.

Johnson, R. T., \& Johnson, D. W. (1986). Action research: Cooperative learning in the science classroom. Science and Children, 24, 31-32.

Johnson, D. W., Skon, L., \& Johnson, R. T. (1980). Effects of cooperative, competitive, and individualistic conditionson children's problem-solving performance. American Educational Research Journal, 17, 83-94.

Knudson, R. (1992). Analysis of argumentative writing at two grade levels. Journal of Educational Science, 85(3), 169-179. doi:10.1080/00220671.1992.9944434

Knupfer, N. N. (1993). Logo and transfer of geometry knowledge: Evaluating the effects of student ability grouping. School Science and Mathematics, 93(7), 360-368.

Larson, M. J., Clayson, P. E., \& Clawson, A. (2014). Making sense of all the conflict: A theoretical review and critique of conflict-related ERPs. International Journal of Psychophysiology, 93(3), 283-297.

Nattiv, A. (1994). Helping behavior and math achievement gain of students using cooperative learning. Elementary School Journal, 94, 285-297.

Palmer, W. (2012). Discovering arguments: An introduction to critical thinking, writing, and style (4th ed.). Boston, MA: Prentice Hall.

Perkins, D. N., \& Tishman, S. (2001). Dispositional aspects of intelligence. In S. Messick \& J. M. Collis (Eds.), Intelligence and personality: Bridging the gap in theory and measurement (pp. 233-257). Maweh, NJ: Erlbaum.

Qin, J., \& Karabacak, E. (2010). The analysis of Toulmin elements in Chinese EFL university argumentative writing. System, 38(3), 444-456.

Saleh, A., Lazonder, W., \& De Jong, T. (2005). Effects of within class ability grouping on social interaction, achievement and motivation. Instructional Science, 33(2), 105-119.

Stapleton, P. (2001). Assessing critical thinking in the writing of Japanese university students: Insights about assumptions and content familiarity. Written Communication, 18(4), 506548.

Tedesco-Schneck, M. (2013). Active learning as a path to critical thinking: Are competencies a roadblock? Nurse Education in Practice, 13(1), 58-60. 
Totten, S., Sills, T., Digby, A., \& Russ, P. (1991). Cooperative learning: A guide to research. New York, NY: Garland.

Toulmin, S. (2003). The uses of argument. Cambridge, UK: Cambridge University Press.

Walker, S. (2003). Active learning strategies to promote critical thinking. Journal of Athletic Training, 38(3), 263-267.

Walton, D. N. (1989). Dialogue theory for critical thinking. Argumentation, 3, 169-184.

Watson, S. B., \& Marshall, J. E. (1995). Effects of cooperative incentives and heterogeneous arrangement on achievement and interaction of cooperative learning groups in a college life science course. Journal of Research in Science Teaching, 32(3), 291-299. doi:10.1002/tea.3660320308

Webb, N. M., Troper, J., \& Fall, J. R. (1995). Constructive activity and learning in collaborative small groups. Journal of Educational Psychology, 87, 406-423. 